\title{
THE ANALYSIS OF ECONOMIC EFFICIENCY OF RED CHILLI BUSINESS IN SAWANG SUBDISTRICT, ACEH UTARA
}

\author{
Adhiana $^{1}$, Martina $^{2}$, Riani $^{3}$, Suryadi $^{4}$ \\ 1,2,3,4 Faculty of Agriculture Universitas Malikussaleh
}

Correspondence Adress: Jalan Cot Teuku Nie-Reuleut Kecamatan Muara Batu, Aceh Utara E-mail: ${ }^{1}$ adhiana@unimal.ac.id, ${ }^{2} \underline{\text { martina@ }}$ unimal.ac.id, ${ }^{3}$ riani@unimal.ac.id, ${ }^{4}$ suryadi@unimal.ac.id

\begin{abstract}
Red chili is one of the horticultural commodities that are needed by the community. However, the productivity of red chili in Aceh Utara is still low at 6.19 tons/ha. This study aims to analyze the factors that affect the production of red chili and analyze the economic efficiency of red chili farming in Sawang Sub-District, Aceh Utara. This research is located in Aceh Utara, precisely in Sawang Sub-District. The sampling method was carried out by census, namely as many as 40 red chili farmers. This study uses a data analysis method, namely the Cobb-Douglas function model with a Stochastic frontier approach. The results of the analysis show that the production factors that affect the production of red chili in Sawang District are land area, labor, and fertilizer, while the seed and pesticide production factors did not affect the red chili production. The results of the study also explained that red chili farming in the research location was technically efficient $(E T=0.796)$, but did not achieve allocative and economical efficiency with the respective averages $(E A=0.439$ and $E E=0.351)$.
\end{abstract}

\section{Key words : Red chili, Production factors, Farming.}

\section{INTRODUCTION}

Red chili is one of the horticultural commodities that are needed by the community with consumption levels that tend to increase every year. In 2018 national red chili production reached 1.21 million tons with a consumption level of $1.56 \mathrm{~kg} / \mathrm{capita} / \mathrm{year}$ and in $2019 \mathrm{red}$ chili production decreased to 1.12 million tons, but the consumption rate increased to $1.58 \mathrm{~kg}$ /capita/year (BPS, 2020). The cycle of red chili demand usually increases in certain months such as Ramadan, while in other months it is relatively constant. Consumption of red chili before the pandemic period was relatively constant, between 61,361 tons per month to 64,930 tons per month, but the highest demand was in the month of Ramadan, which was Rp.54,238 tons (BKP, 2020). At certain times, high demand for red chili is accompanied by high prices and usually occurs in June, which is the dry season and November during the rainy season.(BKP, 2020). Usually in the dry season there are many crop failures due to lack of water and in the rainy season harvest failures due to pests and diseases (Wiryanta, 2011). The high demand for red chili is directly proportional to the increase in population. In addition, red chili is also a staple food ingredient that is always consumed mainly as a cooking spice.

One of the red chili producing areas in Aceh Province is Aceh Utara. The harvested area, production and productivity of red chili in Aceh Utara fluctuated from 2015 to 2018. In 2015 the harvested area reached $65 \mathrm{Ha}$ with a total production of 479.37 tons and a productivity of 7.35 tons/ha. In 2017 the harvested area decreased to 51 Ha with a total production of 310.01 tons and a productivity of 6.19 tons/ha (BPS, 2020). However, red chili production can reach up to 11 tons/ha, this proves that red chili farming in Aceh Utara has not been carried out intensively. 
The main problem is that the production of red chili has not been maximized, one of which is the combination of the use of inputs used in the production process that is not yet efficient. The combination of input use made by farmers will affect the productivity of red chili.According to research results (Pathan, 2019), found that red chili production fluctuates due to several things including the influence of the season, especially the rainy season because a lot of water can cause root rot in red chili plants in Pidie Jaya. In addition, it is also caused by pests and plant diseases because red chilies are generally susceptible to disease. In addition, red chili production is influenced by several production factors including land area, superior seeds, labor, and pesticides.

Various studies have found that the allocation and combination of input use in the production process has not been efficient. Study (Eliyatiningsih 2019), found that chili farming is not efficient in Wuluhan District and is in a position of increasing return to scale. Kewu, F. et al (2020) found thatthe use of production factors in large chili farming in Titigalar Village, namely: seeds, NPK fertilizers, organic fertilizers, pesticides and labor is not efficient and urea fertilizer is not efficient. The inefficient combination of the use of various inputs in red chili farming is caused by various obstacles both from the technical side and from the economic side. So the main problem of the low red chili production in Sawang District is due to the inefficient combination of using various inputs. In addition, farming is generally influenced by various production factors including land, seeds, fertilizers, labor and pesticides. Therefore, it is necessary to identify what factors can be maximized in red chili farming to increase production yields in Sawang District.

\section{LITERATURE REVIEW}

\subsection{Red chili farming}

Farming is how to cultivate and coordinate production factors in the form of land and the surrounding nature as capital, so as to provide the best possible benefits in order to provide the maximum possible income (Suratiyah, 2006). According to Sofia (2015), farming is usually defined as a science that studies how a person allocates existing resources effectively and efficiently for the purpose of obtaining high profits at a certain time. It is said to be effective if farmers can allocate the resources they have (control) as well as possible, and it is said to be efficient if the use of these resources produces output in red chili farming. Red chili (Capcicum Annum, L) is one type of vegetable commodity that cannot be abandoned by people in their daily life. In addition to functioning as a food ingredient, chili also contains many nutrients that are needed for human health such as protein, fat, carbohydrates (Rostini, 2012). Red chili is one of the superior seasonal vegetable crops that is often cultivated because of its high economic value(Sonia, Karyani, and Susanto 2019).

\subsection{Production Theory}

Production is an activity that converts inputs into outputs. These activities in the economy are usually expressed in terms of the production function (Sugiarto et al. 2002). Analysis of the company's production activities is said to be in the short term if some of the factors of production are considered fixed in number (fixed input) while in the long term all factors of production can experience changes, which means that each factor of production can be increased if necessary. Soekartawi (2003), stated that production factors are often referred to as "production victims", because these production factors are "sacrificed" to produce 
production. Therefore, to produce a product, it is necessary to know the relationship between factors of production (input and output).

\subsection{Production Efficiency}

Efficiency in farming production is a use of production factors is said to be technically efficient if the production factors used produce the maximum product (Nopirin, 2012). It is said to be efficient if the price or allocative efficiency if the value of the marginal product is equal to the price of the relevant factor of production. It is said to be economic efficiency if the farm achieves price efficiency. A red chili farmer is technically said to be more efficient than others if the farmer can physically produce higher production using the same factors of production (Eliyatiningsih, 2019). While price efficiency can be achieved by a farmer if he is able to maximize profits. Economic efficiency can be achieved if both efficiency, namely technical efficiency and price efficiency, also achieve efficiency (Soekartawi, 2010). Efficiency can be interpreted as an effort to use the smallest input to get the maximum production.

Economic efficiency is the allocation of resources for the highest value use. This involves making the best possible use of resources and avoiding wastage. Efficiency can be divided into three, namely technical efficiency, price efficiency and economic efficiency (Yotopaulus, 1976). Technical efficiency is considered as the ability to produce at a limit isoquant, while allocative efficiency refers to the ability to reproduce at a certain level of output using the ratio of inputs at a minimum cost. The combination of these two efficiencies is called economic efficiency (Adhiana and Riani, 2018).

\section{IMPLEMENTATION METHOD}

This study was carried out in Aceh Utara, precisely in Sawang Sub-District. The determination of the location selection was carried out intentionally (purposive sampling) based on the consideration that the sub-district is an area that produces red chili with the largest land area and lowest productivity compared to other sub-districts in Aceh Utara Regency. The population in this study were all red chili farmers in the sub-district, namely 40 farmers. Sampling in this study used the census method, where the entire population was sampled. According to Arikunto (2012), if the total population is less than 100 people, it is better if the total number of samples is taken. The data used in this study are primary data and secondary data. Primary data is data obtained through direct interviews using a list of questions or questionnaires to respondents at the research site. Secondary data is data obtained from relevant agencies such as BPS Aceh Utara, Aceh Utara Agriculture Service, literature studies, books and articles related to research such as data on land area, production and productivity of red chili farming in Aceh Utara Regency.

\section{Data Analysis Method}

\subsection{Cobb-Douglas Function Model as Frontier Production Function}

The method used in this study is a quantitative descriptive method using the CobbDouglas production function which can be written as follows:

$\mathrm{Y}=\beta 0 \mathrm{X}_{1}{ }^{\beta 1} \mathrm{X}_{2}{ }^{\beta 2} \mathrm{X}_{3}{ }^{\beta 3} \mathrm{X}_{4}{ }^{\beta 4} \mathrm{e} \mathrm{u}$

The Cobb-Douglas production function is converted into a linear function using the Stochastic Frontier approach. The stochastic frontier production function is chosen based on 
the assumption that the production level achieved by farmers is close to the maximum (frontier) condition, so that it is possible or not to increase productivity on the same land. This method is also used to see technical efficiency, as Coelli (1996) uses the Frontier production function as follows:

$$
\operatorname{Ln} Y=\beta_{0}+\beta_{1} \operatorname{Ln} X_{1}+\beta_{2} \operatorname{LnX}_{2}+\beta_{3} \operatorname{Ln} X_{3}+\beta_{4} \operatorname{LnX} X_{4}+\beta_{5} \operatorname{Ln} X_{5}+v i-\mu i
$$

Information :

$\mathrm{Y} \quad=$ Red Chili Production $(\mathrm{Ton} / \mathrm{Ha})$

$\mathrm{X}_{1} \quad=$ Land area $(\mathrm{Ha})$

$\mathrm{X}_{2} \quad=$ Seeds $(\mathrm{Kg})$

$\mathrm{X}_{3} \quad=$ Fertilizer $(\mathrm{Kg})$

$\mathrm{X}_{4} \quad=$ Labor $(\mathrm{HOK})$

$\mathrm{X}_{5} \quad=$ Pesticide (Liter/Year)

$0 \quad=$ intercept (constant)

$\mathrm{j} \quad=$ Estimation parameter, where $\mathrm{j}=(1,2,3,4,5)$

$\mathrm{vi}-\mu \mathrm{i}=$ Error term $(\mu 1=$ effect of technical inefficiency in the model $)$

The unbiased parameter estimation method is the Maximum Likelihood Estimation (MLE) method. The sign and magnitude of the expected coefficient values are $\beta_{1}, \beta_{2}, \beta_{3}, \beta_{4}, \beta_{5}$ $>0$. A positive coefficient value means that with increasing use of these production factors, red chili production is expected to increase as well. While the negative value of the coefficient will apply the opposite, namely if there is an additional use of these inputs in the production process, it will reduce the production of red chili.

\subsection{Price or Allocative Efficiency}

According to Debertin (1986), to measure allocative and economic efficiency, it is done by deriving the dual cost function from the homogeneous Cobb-Douglas production function. By assuming that the Cobb-Douglas production function uses two inputs, they are as follows:

$$
\mathrm{Y}=\beta_{0} \mathrm{x}_{1}{ }^{\beta 1} \mathrm{x}_{2}{ }^{\beta 2}
$$

The input cost function is as follows:

$$
\mathrm{C}=\mathrm{P}_{1} \mathrm{x}_{1}+\mathrm{P}_{2} \mathrm{x}_{2}
$$

The form of the dual cost function can be derived using the assumption of cost minimization with the constraint $\mathrm{Y}=\mathrm{Y} 0$. To obtain the dual function, it is necessary to obtain the value of the expansion path which can be obtained with the Lagrange function, so simply the following equation will be obtained:

Where :

$$
\mathrm{C}_{\mathrm{i}}=\mathrm{k} \prod_{j=1}^{b} P \mathrm{x}_{\mathrm{ji}}{ }^{\alpha \mathrm{j}} . \mathrm{Y}_{0}^{\mathrm{r}}
$$

$$
\alpha=\mathrm{r} \beta_{\mathrm{i}} \quad \mathrm{r}=\left[\sum_{j} \beta \mathrm{j}\right]^{-1} \quad \mathrm{k}=\frac{1}{r}\left[\beta o \prod_{j} \beta \mathrm{j}^{b j}\right]^{-\mathrm{r}}
$$

So that the following equation is obtained:

$\operatorname{Ln} C=\ln \mathrm{K}+\alpha_{1} \operatorname{Ln} \mathrm{P}_{1}+\alpha_{2} \operatorname{Ln} \mathrm{P}_{2}+\alpha_{3} \operatorname{Ln} \mathrm{P}_{3}+\alpha_{4} \operatorname{Ln} \mathrm{P}_{4}+\alpha_{5} \operatorname{Ln} \mathrm{P}_{5}+r \operatorname{Ln} \mathrm{Y}_{0}$

Based on the approach found by Kopp and Diewert (1982) in Taylor et al. (1986) that allocative efficiency is calculated through the ratio of total costs using the following equation.

$$
\mathrm{AE}=\frac{P j \cdot X c}{P i \cdot X b}
$$

\subsection{Economic Efficiency}


Economic efficiency is achieved when technical and allocative efficiency is achieved. Economic efficiency is the product of technical efficiency and price efficiency of all input factors. The efficiency of cassava farming can be stated as follows:

$$
\mathrm{EE}=\mathrm{TE} \times \mathrm{AE}
$$

Where :

$$
\begin{aligned}
& \mathrm{EE}=\text { Economic Efficiency } \\
& \mathrm{TE}=\text { Technical Efficiency } \\
& \mathrm{AE}=\text { Allocative Efficiency }
\end{aligned}
$$

\section{RESULTS AND DISCUSSION}

\subsection{Estimation of Production Function with MLE Method}

The estimation result of the MLE (Maximum Likelihood Estimation) production function is a result that can be interpreted with the stochastic frontier production function model. The results of the estimation of the MLE (Maximum Likelihood Estimation) method on red chili farming in Sawang District can be seen in Table 1 below:

Table 1. Frontier Function Analysis with MLE (Maximum Likelihood Estimation) approach

\begin{tabular}{clrr}
\hline Parameter & \multicolumn{1}{c}{ Variable } & Coefficient & \multicolumn{1}{c}{ t-Ratio } \\
\hline$(1)$ & \multicolumn{1}{c}{$(2)$} & $(3)$ & \multicolumn{1}{c}{$(4)$} \\
\hline$\beta_{0}$ & Intercept & -3.6512 & $-2.7613^{* * *}$ \\
$\beta_{1}$ & Land Area (X1) & 1.0420 & $4.0158^{* * *}$ \\
$\beta_{2}$ & Seeds (X2) & 1.9245 & $0,0135^{\text {ns }}$ \\
$\beta_{3}$ & Fertilizer (X3) & -0.0535 & $16.1473^{* * *}$ \\
$\beta_{4}$ & Labor (X4) & 0.4632 & $2.8673^{* * *}$ \\
$\beta_{5}$ & Pesticide (X5) & 2.1931 & $0,9609^{\text {ns }}$ \\
\hline Sigma-squared $\left(\sigma^{2}\right)$ & & 0.5772 & 2.3392 \\
Gamma $(\gamma)$ & & 0.8206 & 9.4246 \\
Log Likelihood Function & & & -20.8018 \\
Likelihood Ratio $($ LR) & & & 12,2253 \\
\hline
\end{tabular}

Source: Primary Data (processed)

Note: ***real $\alpha=1 \%(2.67572),{ }^{*}$ real $\alpha=5 \%(2.00758) *$ real $\alpha=10 \%(1.67528) \mathrm{ns}=$ not significant

Based on Table 1 above, it can be seen that the values of sigma-squared $\left(\sigma^{2}\right)$ and gamma $(\gamma)$ resulting from the estimation of the MLE method are 0.5772 and 0.8206 , significant at an error rate of $1 \%$. The value $\sigma^{2}$ which is greater than 0 indicates that there is an influence of technical inefficiency in the model and shows that the distribution of the error term $(\mu \mathrm{i})$ is normally distributed. This is in accordance with the reference that $\sigma>0$ then there is the influence of technical inefficiency (Greene in Adhiana, 2018) and if $\sigma>0$ then the distribution of the error term is normally distributed (Elly in Nauli, 2017).

The gamma value $(\gamma)$ of 0.8206 in the table above is the ratio between the deviation of technical inefficiency $(\mu \mathrm{i})$ to the deviation that may be caused by a random variable (vi). Statistically, the value of gamma $(\gamma)$ of 0.5772 indicates that technical efficiency is much influenced by factors in the management of farmers in their business. Thus the frontier 
production function model used in this study is declared perfect because the variations in the frontier model occur not due to chance, but due to technical inefficiency.

Table 1 above also shows the value of the generalized-likelihood ratio (LR) of 12.2253, which is greater than the value of the code and palm table of $11.383 \alpha=10 \%$. This means that the stochastic frontier function can explain the existence of technical efficiency and inefficiency in the red chili production process in Sawang District. From the results of the analysis of the frontier function using the MLE method in the table above, the stochastic frontier production function model in red chili farming can be written in the following equation:

Ln $Y=-3,6512+1,0420 \operatorname{LnX}_{1}+1,9245 \operatorname{LnX}_{2}-0,0535 \operatorname{LnX}_{3}+0,4632 \operatorname{LnX}_{4}+2,1931$

$$
\mathrm{LnX}_{5}+\mathrm{vi}-\mu \mathrm{i}
$$

The following is the interpretation of each factor of production from the estimation of the stochastic frontier production function model.

1. Land area

The variable area of land has a significant and positive effect on the production of red chili $\alpha=1 \%$ with a coefficient value of 1.0420 . This value indicates that if the area of land is added by $1 \%$ it will increase the production of red chili by $1.0420 \%$ with the assumption that other variables are considered constant (cateris paribus). Graphically, the production function shows that the area of land with an elasticity value of 1.0420 is in the first stage, which means that its use is not efficient, because the Ep value $>1$. This result illustrates that the wider the area of land used by red chili farmers, it will increase production. Because the land in the research location is fertile, well-watered and suitable for red chili plants. The results of this study are in line with the research of Apriani (2011), which states that land area has a significant and positive effect on onion production with a land area elasticity value of 1.202.

2. Seeds

The seeds variable had no significant and positive effect on red chili production $\alpha=1 \%$ with a value of 1.9245 . This value indicates that if the seeds are added by $1 \%$ it will increase the production of red chili by $1.9245 \%$ with the assumption that other variables are considered constant (cateris paribus). Graphically, the production function shows that seeds with an elasticity value of 1.9245 are in stage one, which means their use is not efficient, because the Ep value $>1$. Red chili farmers in the study area use $0.14 \mathrm{~kg} / \mathrm{ha}$ of seed on average, this indicates that the seeds used must be added in order to affect production. according to(Eliyatiningsih 2019), the seed variable has no significant effect on the production of red chili. The use of seeds has a relatively small effect on the productivity of large chilies(Saptana1 et al. 2010).

\section{Fertilizer}

The fertilizer variable has a significant and negative effect on the production of red chili with a value of -0.0535 . This shows that if the amount of fertilizer is increased by $1 \%$ it will reduce the production of red chili by $0.0535 \%$ with the assumption that other variables are considered constant (cateris paribus). Graphically, the production function shows that fertilizer with an elasticity value of -0.0535 is in the third stage, which means its use is inefficient, because the value of $\mathrm{Ep}<0$. The decrease in red chili production in the research location was due to excessive use of fertilizer. The results of this study are in line with the results of the study(Sonia, Karyani, and Susanto 2019), the decline in red chili production was due to the balance of the use of $\mathrm{N}$ fertilizer with other inputs. 


\section{Labor}

The labor variable has a significant and positive effect on cassava production $\alpha=1 \%$ with a value of 0.4632 . This value indicates that if labor is added by $1 \%$ it will increase cassava production by $0.4632 \%$ with the assumption that other variables are considered constant (cateris paribus). Graphically the production function, labor with an elasticity value of 0.4632 is in the second stage, which means its use is efficient, because the value $0<\mathrm{Ep}<1$. The use of labor in the research location is in accordance with what was expected by farmers. The results of this study are in line with research(Fauzan 2014), which states that the use of labor has a significant and positive effect on shallot production in Bantul Regency with a coefficient value of 0.51298 .

\section{Pesticide}

The pesticide variable has no significant and positive effect on the production of red chili with a coefficient value of 2.1931 . This shows that if the amount of pesticide is increased by $1 \%$ it will increase the production of red chili by $2.1931 \%$ with the assumption that other variables are considered constant (cateris paribus). This research is in line with research(Adhiana 2020), where pesticides had no significant effect on cassava production.

\subsection{Technical Efficiency Analysis}

The efficiency index value of the analysis can be categorized into 0.7 is said to be inefficient and $>0.7$ is said to be efficient(Adhiana 2020). The average level of technical efficiency of red chili plants in Sawang Sub-District is 79.6\%. This shows that on average the respondent farmers still have the opportunity to obtain more efficient results, as has been obtained by farmers who have maximum technical efficiency. Opportunities that are owned and can be done by farmers are by increasing the technical efficiency of red chili plants by allocating the use of production factors according to the needs of red chili plants and optimal use of inputs and by increasing the application of good technical management.

\subsection{Allocative Efficiency Analysis}

This allocative efficiency analysis is intended to determine the rationality of farmers in carrying out farming activities with the aim of making profits. Profits will be maximized if there is a combination of the use of production factors to achieve the highest level of economic efficiency. Allocative and economic efficiency is obtained through analysis of production inputs using input prices prevailing at the farm level. The production function used as the basis for the analysis is the stochastic frontier production function. Then the frontier cost function (isocost frontier) will be obtained as follows:

\section{$\operatorname{LnC}=1,5428+0,1835 \mathrm{LnP}_{1}+0,3390 \mathrm{LnP}_{2}+0,0094 \mathrm{LnP}_{3}+0,0816 \mathrm{LnP}_{4}+0,3863 \mathrm{LnP}_{5}+$ $0,1761 \mathrm{Y}$}

Based on the results of the reduction of the dual cost function in the above equation, the allocative and economic efficiency values can be calculated. The distribution of farmers' allocative and economic efficiency values can be seen in the table below. At the level of input prices prevailing in the study area, on average the respondent farmers are relatively inefficient 
allocatively (0.4394), and when using the combined effect of technical and allocative efficiency, the respondent farmers also become less economically efficient, namely $(0,3501)$. The distribution of technical, allocative and economical efficiency values can be seen in the table below.

Table 2. Distribution of technical, allocative and economic efficiency.

\begin{tabular}{|c|c|c|c|c|c|c|}
\hline \multirow{2}{*}{$\begin{array}{c}\text { Scatter } \\
\text { Efficiency }\end{array}$} & \multicolumn{2}{|c|}{ Technical Efficiency } & \multicolumn{2}{|c|}{ Allocative Efficiency } & \multicolumn{2}{|c|}{ Economic Efficiency } \\
\hline & $\begin{array}{l}\text { Number of } \\
\text { respondents }\end{array}$ & $\begin{array}{c}\text { Percentage } \\
(\%)\end{array}$ & $\begin{array}{l}\text { Number of } \\
\text { respondents }\end{array}$ & Percentage $(\%)$ & $\begin{array}{l}\text { Number of } \\
\text { respondents }\end{array}$ & $\begin{array}{c}\text { Percentage } \\
(\%)\end{array}$ \\
\hline 0.7 & 9 & 22.5 & 38 & 95 & 39 & 97.5 \\
\hline $0.71-0.9$ & 21 & 52.5 & 1 & 2.5 & 0 & 0 \\
\hline $0.91-1.0$ & 10 & 25 & 1 & 2.5 & 1 & 2.5 \\
\hline Total & 40 & 100 & 40 & 100 & 40 & 100 \\
\hline Average & 0.796 & & 0.439 & & 0.351 & \\
\hline Minimum & 0.1921 & & 0.298 & & 0.284 & \\
\hline Maximum & 0.9238 & & 0.997 & & 0.999 & \\
\hline
\end{tabular}

Source: Processed data (2021)

In this researchfound that the average value of technical, allocative and economic efficiency were $79 \%, 44 \%$, and $35 \%$, respectively. Respondent farmers who have an allocative and economic efficiency value greater than 0.7 are $5 \%$ and $2.5 \%$, respectively. Meanwhile, farmers who have an allocative and economic efficiency value less than $0.7 \%$ are $95 \%$ and $97.5 \%$, respectively.

The allocative efficiency of red chili farmers in the study area is in the range of 0.298 to 0.997 . This shows that if rOn average, red chili farmers in Sawang Sub-district wish to achieve the highest level of allocative efficiency, so they have to save costs by $56 \%$ (1$0.439 / 0.997)$, while farmers who are inefficient, they have to save $70 \%$ (1- 0.997). 0.298/0.997). Meanwhile, the combined effect of technical and allocative efficiency shows that the economic efficiency of red chili farmers in Sawang District is in the range of 0.284 to 0.999. This shows that if the average red chili farmer in the study area wishes to achieve the highest level of economic efficiency, then they have to save costs by $65 \%$ (1-0.351/0.999), while farmers who are inefficient, they have to save costs by as much as 65\%.71\% (1- 0.284/0.999). Add research(Waryanto 2016), the EA value ranges from 0.186 to 0.978 , with an average value of 0.639. ET and EA values can be used as a benchmark in assessing the relative success of a farm. Based on the economic efficiency (EE) has not been achieved because the average value of EE is only 0.509. From the EE figure, to get the maximum profit, shallot farmers must save the cost of purchasing production inputs by 33.38 percent. 


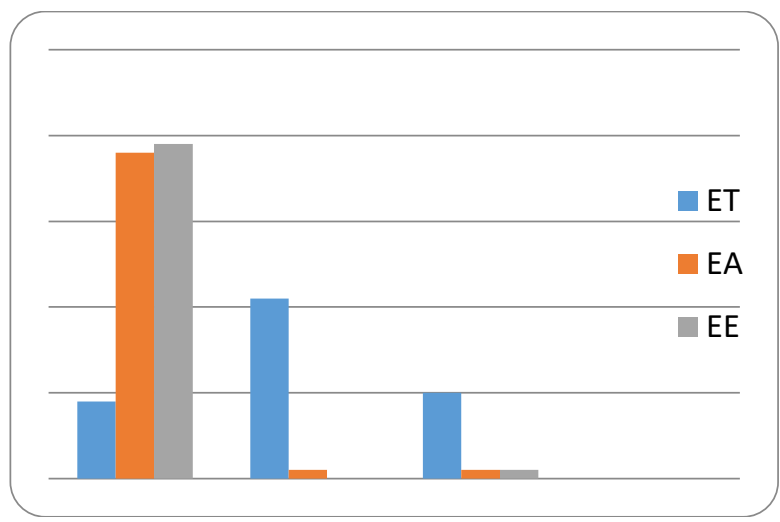

Figure 1. Distribution of Technical, Allocative and Economical Efficiency of Red Chili Farmers Using the Stochactic Frontier Production Function

Based on the results of the analysis, it is found that the handling of allocative efficiency problems is more important when compared to technical efficiency problems in an effort to achieve a higher level of economic efficiency. Achieving a high level of economic efficiency will increase farmers' income and profits.

\subsection{Red Chili Farming Economic Efficiency}

Economic efficiency is a combination of technical efficiency and allocative efficiency. If a farm is technically efficient and allocatively efficient, then the farm is said to be economically efficient. Mathematically, economic efficiency is stated as follows:

$$
\begin{aligned}
& \mathrm{EE}=\mathrm{TE} . \mathrm{AE} \\
& \mathrm{EE}=0.7968 \times 0.4394 \\
& \mathrm{EE}=0.3501
\end{aligned}
$$

The average value of technical efficiency is 0,7968 This means that red chili farming in Sawang District is efficient. Allocatively, the efficiency value of 0.3501 means red chili farmingnot yet efficient, in order to achieve efficiency, the use of several production factors needs to be increased, such as the number of workers and seeds for a one hectare land area.The value of economic efficiency in red chili farming in Sawang District is 0.3501 which means that it is not yet economically efficient. This result is different from the study by Willibrordus Lanamana (2017), that the average level of economic efficiency of Nggela corn farming is in the high category, which is 0.87 or $87 \%$.

\section{CONCLUSIONS AND THANK-YOU NOTE \\ 5.1.Conclusion}

a. From the estimation results using the Stochastic Frontier production function, it was found that the variables of land area, fertilizer, and labor had a significant effect on red chili production. While the variables of seeds and pesticides have no significant effect on the production of red chili.

b. Red chili farming in Sawang District has achieved technical efficiency with rthe average level of technical efficiency is $79.6 \%$, meaning that in the short term red chili farmers still have the opportunity to be increased by $20.4 \%$ by applying the skills, experience and cultivation techniques by the most efficient farmers. However, the average allocative 
efficiency value is $43.9 \%$ and the economic efficiency value is $35.1 \%$. This means that red chili farming in Sawang District is still economically inefficient.

\subsection{Thank-You Note}

The authors would like to thank the entire research team who have provided input in the research design process, discussion of results and discussion. Thanks also to LPPM Unimal for providing financial support for this research.

\section{REFERENCES}

Adiana. 2020. "Analysis of Allocative Efficiency of Cassava Farming in Tanjung Morawa District, Deli Serdang Regency, North Sumatra Province.” AGRIFO Vol. 5 (2).

Adhiana, and Riani, 2018. Analysis of Farming Economic Efficiency: Stochastic Production Frontie Approach. Lhokseumawe: Sefa Bumi Persada

Arikunto, S. 2014. Research Procedures A Practical Approach. Jakarta: Rineka Cipta.

Amandasari, M. 2014. Technical Efficiency of Sweet Corn Farming in Tanjolaya District, Bogor Regency: Data Envelopment Analysis (Thesis) Approach. Postgraduate Program, Bogor Agricultural University. Accessed from https://repository.ipb.ac.id/handle/123456789/72899

Apriani, LN 2011. Analysis of Technical Efficiency and Income of Shallot Farming (Case Study: Sukasari Kaler Village, Argapura District, Majalengka Regency, West Java Province) (Thesis). Undergraduate Program, Bogor Agricultural University. Accessed fromhttps://repository.ipb.ac.id/handle/123456789/53166

Central Bureau of Statistics. 2020. Aceh Utara Regency in Figures. Aceh Utara

BKP. Food Security Agency. 2020. Prognosis of production and basic/strategic food needs in 2020 period January-December 2020 (Jan-June realization and July-December prognosis, Update 18 July 2020). Jakarta (ID): Food Security Agency.

BPS. 2020. Distribution of Red Chili Commodity Trade in Indonesia 2019 .https://www.bps.go.id/publication/2020/01/13/e551727c6b440d31490770b8/distributionperdagangan-k Commodity-red-chili-in-indonesia-2019.html

Debertin, D. 1986. "Agricultural Production Economics. Macmillan Publishing Company".

Eliyatiningsih. 2019. "Efficiency of Use of Production Factors in Red Chili Farming in Wuluhan District, Jember Regency." Agrica Vol.12 No.

Fauzan, Muhammad. 2014. "Profitability and Technical Efficiency of Shallot Farming in Bantul and Nganjuk Regencies." SEPA: Journal of Socio-Economic Agriculture and Agribusiness 11 (1): 35. https://doi.org/10.20961/sepa.v11i1.42248. 
Khotimah, H. 2010. Analysis of Technical Efficiency and Income of Sweet Potato Farming in Cilimus District, Kuningan Regency, West Java (Thesis). Undergraduate Program, Bogor Agricultural University.

Accessed fromhttps://repository.ipb.ac.id/handle/123456789/60673

Nopirin. 2012. Introduction to Macro Microeconomics. Yogyakarta: BPFE Yogyakarta.

Putri, R., Murdani, \& Fadli. 2016. Analysis of Technical Efficiency in Soybean Farming (Glycine max (L.) Merril) in Peudada District, Bireun Regency, Aceh. Journal of Agrium, 12(1), 16-22.

Rostini. 2012. Pest and Disease Free Chili Planting Strategy. Agromedia Library. East Kalimantan

Suratiyah, K. 2009. Farming Science. Self-Help Spreader. Jakarta

Saptana1, Arief Daryanto2, Heny K. Daryanto, and and Kuntjoro. 2010. "Analysis of Technical Efficiency of Red Chili Farming Production and Farmer Behavior in Facing Risk." Agroeconomy 28 (2).

Soekarno. 2003. Agribusiness Theory and Its Application. King Grafindo Persada. Jakarta.

Sonia, Tina, Tuti Karyani, and Agus Susanto. 2019. "Analysis of Allocative Efficiency of Big Red Chili Farming in Suka Laksana Village, Banyuresmi District, Garut Regency" 6 (1): 19-32.

Waryanto, Budi. 2016. "Analysis of Technical Efficiency, Economic Efficiency and Competitiveness in Shallot Farming in Nganjuk Regency, East Java: An Econometric and Pam Approach.” Agricultural Informatics $23 \quad$ (2): 147. https://doi.org/10.21082/ip.v23n2.2014.p147-158.

Lau. LJ and PAYotopaulus. 1979. The Methodological Framework of Profit Function Food Research. Food Research Institute Studies. 
